\title{
RECENT DEVELOPMENTS IN POLITICAL GEOGRAPHY, I*
}

\author{
RICHARD HARTSHORNE \\ University of Minnesota
}

The border position of geography between the natural and the social sciences is fairly generally recognized. Concerned primarily with differences in the different areas of the world, geography studies both natural and cultural features. In some universities, it is included among the natural sciences, in others among the social sciences. In England and America, geographers have particularly cultivated that portion of their field which leads naturally into economics, i.e., economic geography. Much less attention has been paid to the relations with history, although various geographers and historians have studied what has variously been called historical geography or geographic history. Even less have geographers in the English-speaking countries concerned themselves with that portion of their subject which bears upon the political areas of the world. The territorial problems of the war and postwar period, however, stimulated activity in this field both in England and America, the most notable product of which is Bowman's The New World, consisting in large part of the materials gathered for the American Commission to the Peace Conference. ${ }^{1}$

With that one exception, no major work in political geography has been published in the United States, and not more than two or three in England. It is therefore perhaps not surprising to find this branch of the field handled very briefly, if at all, in the various resumés that have recently been published in this country concerning the general field of geography. ${ }^{2}$

* This paper is, in part, a result of studies made as a fellow of the Social Science Research Council in 1931-32.

${ }^{1}$ Isaiah Bowman, The New World: Problems in Political Geography (Chicago, 1921, 4th ed., 1928). Dr. Bowman was chief territorial adviser and executive officer of the Section of Territorial, Economic, and Political Intelligence.

2 In the most detailed of these, Isaiah Bowman, Geography in Relation to the Social Sciences (Part V of the Rept., Comm. on Soc. Stud., Amer. Hist. Assoc., New York, 1934), political geography is discussed in ten pages (pp. 205-215), with almost no bibliography. In Carl Sauer's chapter on "Cultural Geography" in Recent Developments in the Social Sciences (Phila. and London, 1927), three pages are devoted to this branch of the field (pp. 207-210), chiefly criticisms, in part justified but based on an evidently very limited survey. In Jean Brunhes' chapter on " $\mathrm{Hu}$ man Geography" in History and Prospects of the Social Sciences (H. E. Barnes, 
Nowhere in English can I find an adequate summary, to say nothing of a discussion, ${ }^{3}$ of the notable developments of the past twenty years in political geography on the Continent, particularly by the Germans. ${ }^{4}$ It is unfortunate that this work should remain largely unknown to political scientists and historians, as well as to geographers, in this country. For this reason, the writer has prepared this paper, which, it is hoped, may also help to clear up misunderstandings as to the character of the subject. The paper will therefore present briefly the historical development of the field, explain the various concepts of the subject held by different groups of workers, and describe the scope of the field thus defined. ${ }^{5}$

\section{HISTORY OF THE FIELD}

Political Geography Before the World War. While it is true that the greatest developments in this field owe their stimulus to the changes caused by the World War, it is incorrect to consider political geography as a new field of knowledge first opened up at that time. In a sense, it is as old as the science of geography itself. ${ }^{6}$

ed., New York, 1925), the discussion of political geography, pp. 71-74, 101-102, is limited almost entirely to a consideration of one book, that of Brunhes and Vallaux. (Cf. Sauer's comments on Brunhes' treatment of his subject). In the $E n$ cyclopedia of the Social Sciences, political geography appears only in a short paragraph under "Political Science" in which only Ratzel and Kjellén are mentioned. (For contrast, see "Politische Geographie" in the Staatslexicon, or the Politisches Handwörterbuch.)

${ }^{3}$ A small exception is offered in the utilization of recent work of German students on the geography of political boundaries, in my "Geographic and Political Boundaries in Upper Silesia," Annals Assoc. Amer. Geog., Dec., 1933, pp. 195-228.

" That the Germans should be particularly interested in the subject since the War is obvious, but they have always shown more interest in it than has any other group. The environmental reasons for this, as well as for the lack of interest in this country, are discussed by Derwent Whittlesey in "Environment and the Student of Human Geography," Scientific Monthly, 1932, pp. 265-267.

s The references in the footnotes provide a considerable up-to-date bibliography, not readily available elsewhere. The largest bibliography, including references to over 700 writers and fairly complete through 1924, is given in the footnotes of Otto Maull, Politische Geographie (Berlin, 1925), especially pp. 703-710. Bowman, The New World, pp. 747-775, presents also a very large bibliography of a different sort, consisting chiefly of references to materials in economic geography, history, politics, etc., of value for the study of different countries. The writer regrets that he is limited to the literature in English, French, and German. In none of the bibliographies studied are there more than one or two important titles in any other modern language, though Haushofer speaks, in passing, of "prominent students of Geopolitik in Fascist Italy."

- For a detailed discussion of the development of political geography, see Maull, op. cit., pp. 1-30. 
If Herodotus was a geographer, he was also a political geographer; Strabo certainly was both, as his description of the geographic basis of the Roman Empire shows. The relation of states to the natural conditions of their areas has been a subject of speculation of historians and philosophers as well as geographers from Plato through Montesquieu and $\mathrm{Kant}^{7}$ to the present time. These speculative students developed a great wealth of hypotheses which they were not in a position to prove, but which provide a stimulating body of ideas for present students in the field, and which should make it unnecessary for them to spend much effort in that phase of investigation. ${ }^{8}$

In contrast to the hypothetical work of the philosophic writers, Carl Ritter, often called the founder of modern geography in Germany, first attempted (1817) to base conclusions of political geography on the growing body of material of physical geography. Since then, a whole host of geographers have considered this subject, chiefly in terms of the relation of physical geography to political and military history. ${ }^{9}$

Among the earlier workers were two of Ritter's disciples, the Swiss-American, Guyot (1849), and the early master of French geography, Elisée Reclus (L'Homme et la terre, 6 vols., 1905-08); the Russian geographer Metchnikoff, who wrote on the relation of civilization to the great river valleys (1889); a group of German writers headed by H. F. Helmolt, who published nine volumes of geographic history under the title of Weltgeschichte (1899, later

7In his discussion of geography, Immanuel Kant provides for a political geography "founded entirely on physical geography." "Kant's Physiche Geographie," Philos. Bibl., B.A. 51, 2 Aufl. (Leipzig, 1904), p. 17 (after Maull).

- At least one of these hypotheses is of special interest in comparison with certain current theories. The Arab historian, Ibn Chaldun, held that the fourth temperature zone, of the seven zones of the Arab geographers, was the most favorable for civilization, as shown by the lands included in it-those of the Arabs, Romans, Persians, Jews, Greeks, Hindus, and Chinese. Maull, op. cit., p. 8.

- Two non-geographers, a French historian, Febvre, and an American sociologist, Franklin Thomas, have made excellent detailed studies of the development of thought in this field, though Febvre's study was in fact written about 1914 and Thomas was not acquainted with the recent work in Germany. Both writers give somewhat exaggerated impressions of the importance of this aspect of geography in the general field, since neither is familiar with more recent developments. Lucien Febvre, La terre et l'evolution humaine (in the series "L'Evolution de l'Humanite," 2d. ed., Paris, 1924), trans. as $A$ Geographical Introduction to History (in the series "The History of Civilization," New York, 1925); Franklin Thomas, The Environmental Basis of Society; A Study in the History of Sociological Thought (New York, 1925). 
translated into English); two English geographers, Mackinder (1890) and Hereford George (1901); and three American geographers who studied the relation of geography to American history: Shaler (1891), Brigham (1903), and Semple (1903). ${ }^{10}$

More recently, there have been significant contributions by Fairgrieve, Cornish, and Kermack in England, and by Semple and Wright in America, not to mention the works in foreign languages. ${ }^{11}$ Huntington's special studies of the relation of climate to history are well-known. ${ }^{12}$ In addition, the standard geographies of major world regions, such as those of Lyde, Mackinder, Partsch, Hettner, etc., have usually included sections on historical or political geography..$^{13}$

${ }^{10}$ The dates are those of the first publications of the respective writers in this field. Titles of these and a number of similar works may be found in the bibliography in Thomas, op. cit., pp. 317-329. Two have recently been republished: Hereford B. George, The Relations of Geography and History (rev. and enl. by Howarth and Fawcett, Oxford, 1924); Ellen C. Semple, American History and Its Geographic Conditions (rev. by C. F. Jones, Boston, 1933). Mackinder enlarged upon his earlier papers, notably "The Geographical Pivot of History" (Geog. Jour., April, 1904), in which Haushofer finds much of the world history of 1914-24 correctly predicted, in Democratic Ideals and Reality (London, 1919).

11 James Fairgrieve, Geography and World Power (London, 1915, 1921); V. Cornish, The Great Capitals; An Historical Geography (London and New York, 1922); W. R. Kermack, Human Environment and Progress; The Outline of World Historical Geography (chiefly the British Isles) (Edinburgh and London, 1927), and two previous studies of Scotland and the British Empire; Ellen C. Semple, Geography of the Mediterranean Region: Its Relation to Ancient History (New York, 1931); J. K. Wright, The Geographical Basis of European History (New York, 1928). To these should be added the study of this continent by the English geographer, Rodwell Jones, Part I of Ll. R. Jones and P. W. Bryan, North America; An Historical Economic, and Regional Geography (New York, 1924), and especially C. O. Paullin (J. K. Wright, ed.), Atlas of the Historical Geography of the United States (New York, 1932), abstract by Wright: "Sections and the National Growth," Geog. Rev., 1932, pp. 353-360.

12 Of Ellsworth Huntington's many publications, the most significant in this connection are World Power and Evolution (New Haven, 1919), and two studies of the geography of Biblical history: Palestine and Its Transformation (Boston, 1911) and Chaps. XII-XVII in The Pulse of Progress, Including a Sketch of Jewish History (New York, 1926).

is Aside from these well-known works, mention might be made of two early ones: C. Naumann and Josef Partsch, Physikalische Geographie von Griechenland, mit besonderer Rücksicht auf das Altertum (Breslau, 1895), pp. $97 \mathrm{ff}$; Theobald Fischer, "Die iberische Halbinsel," in Kirkchhoff's Länderkunde von Europa (Vienna, 1893), Pt. 2, 2nd half; and of two more recent: Alfred Hettner, Russland, eine geographische Betrachtung von Volk, Staat, und Kultur (Leipzig, 1916); and I. Bowman, Desert Trails of Atacama (New York, 1924), Chap. V. 
In the field of political geography as distinct from the more general historical geography, the foundations were laid by Friedrich Ratzel, whose Politische Geographie, ${ }^{14}$ published in 1897, is universally recognized as the first systematic treatment of the subject. ${ }^{15}$ In France, where his Anthropogeographie was already well known, this volume was discussed at great length by Vidal de la Blache, ${ }^{16}$ a condensed article by Ratzel was published in French, ${ }^{17}$ and Vallaux later used the Politische Geographie as the basis, at least for departure, of his two volumes in the same field. ${ }^{18}$

Unfortunately, Miss Semple, on whom geographers in England and America have largely depended for their knowledge of Ratzel's ideas, did little with his political geography..$^{19}$ In this field, a more important follower was the Swedish political scientist Kjellén, whose work was to have such a profound influence on the development of the subject in Germany after the World War. But for a generation Ratzel's work was almost the only major authority in the field, the framework for studies by Hassert, Schöne, ${ }^{20}$ Sieger, Maull, Haushofer, and a few others.

On the whole, however, Ratzel's study did not have the effect that he expected. Geography was for some time carried along in the general up-swing of the physical sciences (especially in America under the leadership of W. M. Davis). It was not until the World War emphasized the need for development of the social sciences in general, and in particular stimulated popular as well as academic

14 Fr. Ratzel, Politische Geographie (Munich, 1897); 2nd. ed. with additional title oder die Geographie der Staaten, der Verkehrs, und des Krieges, 1903; 3rd. ed. rev. with chapter on the historical development of the subject by E. Oberhummer, (Munich and Berlin 1923). In addition should be listed: Das Meer als Quelle der Völkergrösse (Munich, 1900); Die Vereinigten Staaten von Nordamerika, Bd. 2. Politische Geographie (Munich, 1893); and various special studies in Kleine Schriften, 2 vols. (Munich, 1906).

15 Abstract by Otto Schlüter in Z. Geo. f. Erdkunde (Berlin, 1898), pp. 126-140.

16 Vidal de la Blache, "La geographie politique d'après les écrits de M. Fr. Ratzel," abstract and rev. in Ann. de Geog. (March, 1898), pp. 97-111.

17 Ratzel, "Le sol, la societé, et l'état," Année Sociol. 1898-99.

${ }^{18}$ See the preface to each of Camille Vallaux, Geographie sociale: le mer (1908), and Le sol et l'etat (1911, Paris).

10 Though in her great treatise which is derived in large part from his Anthropogeographie she devotes a chapter or so to political geography. E. C. Semple, Influences of Geographic Environment (New York, 1911), Chap. III and parts of Chap. VII.

20 Emil Schöne's little book was intended as "a popularization of the ideas of Ratzel," Politische Geographie (Aus Natur- und Geisteswelt series, Leipzig, 1911). 
interest in political geography, that that part of their subject attracted the attention of many geographers. ${ }^{21}$

Summarizing for the century preceding the World War, the work in the border area between history and political science on the one hand and geography on the other was in large part that of geographers. Although historians have frequently had good reason to object to exaggerated conclusions or too simple generalizations in some of these geographic interpretations of history (compare with the school of economic interpretation), many historians have appreciated the value of the new point of view and methods offered. Thus, the French historian, Febvre, in his masterly examination of the work of this period-especially that of Ratzel, Vallaux, and Vidal de la Blache-pays this tribute: "Anyone nowadays who wants instruction on the relation between the land and historyI mean conscientiously and with guarantees-must apply to them [the geographers] first." ${ }_{22}$

More recently, many geographers have changed their concept of "historical geography" to denote the geography of past periods, and have classified studies of geographic influences in history as "geographic history," i.e., rather a part of the field of history than of geography. ${ }^{23}$ Nevertheless, it was the work of the geographers that brought this subject to the attention of historians like Turner ${ }^{24}$

${ }^{21}$ Nevertheless, Haushofer feels that the subject, as developed by Ratzel, Vallaux, and Mackinder, did have a notable influence on political thought and action in England and France-in the latter through the Ecole de Politique-but unfortunately little or none in Germany. "Politische Erdkunde und Geopolitik," in Freie Wege Vergleichender Erdkunde (Festgabe E. v. Drysgalski, Munich, 1925), pp. $94 \mathrm{ff}$.

${ }^{22} O p$. cit., p. 17. In the bibliography, .pp. 369-379 (mostly French sources), and in that of Franklin Thomas, op: cit., pp. 317-329, are a considerable number of studies in this field by others than geographers. To these should be added E. A. Freeman, Historical Geography of Europe, 2 vols. with atlas (3rd ed. London, 1903).

${ }^{23}$ Brunhes, "Human Geography," in History and Prospects of the Social Sciences, pp. 100-101 (according to Brunhes, Hettner stated this conclusion in the Geog. Z. for 1898); Harlan H. Barrows, "Geography as Human Ecology," Annals Assoc. Amer. Geog., 1922, pp. 11-12; Suaer, op. cit., p. 200. Similar conclusions were expressed at a joint meeting of geographers and historians in England, reported in "What is Historical Geography?", Geography (1932), pp. 39-45.

${ }^{24}$ Frederick J. Turner, The Frontier in American History (New York, 1920); The Significance of Sections in American History (New York, 1932). In a quotation in the introduction to the latter, Turner, it seems to me, very clearly expresses the contrast between the position of an historian and that of a geographer: "The central interest of my [life] study has been that of these maps of population advancenot as a student of a region but of a process." 
and Vogel, ${ }^{25}$ and geographers trust to see other historians, adequately trained in geography, make use of geographical methods and concepts in their historical studies.

The World War and Political Geography. The changes in the political map of Europe which were discussed in all countries during and after the War drew the attention of geographers in America, as well as in Europe, to specific problems in political geography. Many were drawn into active work for their governments, and the following, in particular, functioned as experts at the Peace Conference: Ogilvie for England, de Martonne for France, Romer for Poland, Cvijic for Serbia, and Bowman and Douglas Johnson for the United States. ${ }^{26}$ A large number of others made special studies of particular boundary problems. ${ }^{27}$ Several geographers published somewhat general studies of world political problems for non-academic readers, which expressed purely personal points of view but included much expert information. ${ }^{28}$

Most of these geographers have returned to their former areas of work. On the whole, the products of this period reflect the lack of adequate development of political geography as a discipline, as well as a lack of sufficient grounding of most of the writers in the subject, even so far as it had been developed. Their problems were too complex for either their training or their information, and the nationalist spirit was usually the dominating influence. There were,

${ }_{25}$ Walther Vogel, Das neue Europa und seine historisch-geographischen Grundlagen, 2 vols. (Bonn and Leipzig, 1921, 1925); Politische Geographie (Leipzig, 1922);

Die Entstehung des modernen Weltstaatensystems (Weltpol. Bücherei, Berlin, 1929).

${ }^{20}$ In addition, the following were engaged in cartographic work or prepared other special materials: de Margerie and Gallois (France), Marinelli and Ricchieri (Italy), and Jefferson, Lobeck, and Martin (United States). Sieger, who alone of the list had been an active student of political geography, came to Paris with the Austrian delegation, but had, of course, no opportunity to take part in the work of the Conference. Likewise the material which Teleki sent from Hungary had little effect; he was for a short period prime minister of Hungary. The above list, prepared chiefly from correspondence with several of the Americans mentioned, is probably not complete.

27 Including Partsch, Penck, Krebs, Sapper, Volz, Sölch, Teleki, Gallois, Holdich, and Lyde.

${ }^{28}$ Alfred Hettner, England's Weltherrschaft (Leipzig, 1915, revised 1928); G. Wegener, Die geographische Ursachen des Weltkrieges (Berlin, 1920), summarized in "Erdraum und Schicksal," Z. f. Geopolitik, 1931, pp. 542-57; H. J. Mackinder, Democratic Ideals and Reality (London, 1919); A. Demangeon, Le declin de l'Europe (Paris, 1920, trans. as America and the Race for World Dominion, New York, 1921); O. D. Von Engeln, Inheriting the Earth; or the Geographical Factor in National Development (New York, 1922). 
however, notable exceptions - not only men like Sieger and Maull, who had long been studying political geography, but also others like the physiographers Supan and Penck, who, in spite of intense nationalism, were able to make valuable contributions to the development of theory in the subject. ${ }^{29}$

Political Geography Since the Period of the World War. The stimulus of the war and post-war period had, moreover, its more permanent effects. Especially in Germany, where dissatisfaction with the territorial settlements of the Peace Conference greatly increased popular as well as academic interest in the subject, has political geography developed.

Systematic treatises of the field, based fundamentally on Ratzel, have been published by Supan, Dove, Vogel, Dix, and Maull. ${ }^{30}$ Of these, the most important is Maull's strikingly objective and scholarly, if somewhat too encyclopedic, work. In addition to a great wealth of factual material, the author provides a comparative study of the various points of view of nearly all his predecessors. ${ }^{31}$ Unfortunately, Sieger's plans for a full treatment of the subject were cancelled by his death (1926); his keen analysis and development of precise terminology are available only in a dozen or more articles scattered through various periodicals, some difficult to obtain..$^{32}$

29 Penck, Uber politische Grenzen (Rektoratsrede, Berlin, 1917). (Only the theoretical discussion, the major part, is of value now; it is unfortunate that the applications suggested for Europe, given in an address made during the heat of the war, could not have been omitted in publication.) Supan's work will be noted later. For other work in political geography in Europe during this period, notably that of Fleure, Newbigin, Crijic, and Teleki, see the full list in W. L. G. Joerg, "Recent Geographical Work in Europe," Geog. Rev., 1922, pp. 431-784. In America, the most important-other than Bowman, The New World-were Leon Dominian, The Frontiers of Language and Nationality in Europe (New York, 1917), and Douglas Johnson's studies in the special field of military geography: Topography and Strategy in the War (New York, 1917), and Battlefields of the World War, 2 vols. (New York, 1921).

so Alexander Supan, Leitlinien der allgemeinen politischen Geographie: Naturlehre des Staates (Berlin and Leipzig, 1918, 1922); K. Dove, Allgemeine politische Geographie (Leipzig, 1920); Walther Vogel, Politische Geographie (Leipzig, 1922); Arthur Dix, Politische Geographie: Weltpolitisches Handbuch (Munich, 1922, 1923); Otto Maull, Politische Geographie (Berlin, 1925).

s1 "Without doubt it deserves a distinctly prominent place in the modern geographic literature." J. Sölch, review in Geografiska Annaler, 1925, pp. 251-255. Other reviews by Sieger in Geog. Z., 1926, p. 379, and Schlüter in Geog. Anz., 1926, pp. 62-66.

22 For an appreciation, with full bibliography, see J. Sölch: "Robert Sieger," 
Of special studies in the political geography of certain regions and boundary areas, there have been a great number by Obst, Passarge, Uhlig, Volz, Sölch, and others. ${ }^{33}$

But increasingly the younger German geographers interested in the political aspect of the subject have taken their lead from Karl Haushofer, ${ }^{34}$ the founder (with Obst) and editor of the Zeitschrift für Geopolitik. The work of this school is based in part directly on Ratzel, but particularly on the system of the Swedish political scientist Kjellen, ${ }^{35}$ whose concept of the state as an organism was taken from Ratzel. ${ }^{36}$ Taking the name of Geopolitik from Kjellén, and ultimately enlarging its scope greatly, the members of this group ${ }^{37}$ publishing in their monthly magazine as well as in numer-

Geog. Z., 1927, pp. 305-313. Perhaps the most valuable single reference is "Zur politische-geographischen Terminologie," Z. Ges. f. Erdkunde Berlin, 1917, pp. 497529; 1918, pp. 48-69.

${ }^{33}$ Erich Obst, England, Europa, und die Welt: eine geopolitische-, weltwirtschaftliche Studie (Berlin, 1927); Johann Sölch, various articles on the Tyrol, including "The Brenner Region," in Sociol. Review, Oct., 1927, pp. 1-17; S. Passarge, Ägypten und der Arabische Orient: eine politische-geographische Studie (Weltpol. Bücherei, Bd. 28, Berlin, 1931). Special mention should be made of the cartographic work, as applied to political geography, in W. Volz and H. Schwalm, Die deutsche Ostgrenze, Unterlagen zur Erfassung der Grenzzerreisungsschäden (Leipzig, 1927), and H. Overbeck and G. W. Saute, Saar-Atlas (Gotha, 1934); see my review in Geog. Rev., Oct., 1934, pp. 680-682.

${ }^{34}$ Formerly a regular officer of the German army, Haushofer's intention to transfer to academic life was postponed by the War to 1920, when he retired as a majorgeneral. Now professor at the University of Munich, his best work is on Japan, where he was stationed as military attaché in 1908-11. Karl Haushofer, Dai Nihon: Betrachtungen über Gross-Japans Wehrkraft, Weltstellung und Zukunft (Berlin, 1913); Das Japanische Reich in seiner geographischen Entwicklung (Vienna, 1921); Japan und die Japaner, eine Landes- und Volkskunde (Leipzig, 1923, 1933). For an appreciation of the work of this significant leader, see "Karl Haushofer, zum 60 Geburtstag," Z. f. Geopolitik, 1929, pp. 709-725.

${ }^{36}$ Rudolf Kjellén (1864-1922). For an appreciation of his work, see "Kjellén" (by Vogel) in Encyc. Soc. Sciences, or, in more detail, by Sieger in Z. f. Geopolitik, 1924, pp. 339-346. Most important of his studies were: Stormakterna, 4 vols. (Stockholm, 1910-14 (trans. Die Grossmächte der Gegenwart, Leipzig, 1915, 22d ed., ed. by K. Haushofer, Die Grossmächte vor und nach dem Weltkriege, Berlin and Leipzig, 1930); Staten som lifsform (Stockholm, 1916, trans. Der Staat als Lebensform, Berlin, 1917, 1924); Grundriss zu einem System der Politik (Berlin, 1920).

${ }^{86}$ In addition to the work of Ratzel and Kjellén, Haushofer lays particular emphasis on Fairgrieve's study, op. cit., which he has had published in German (trans. by Martha Haushofer, his wife) with an introduction by himself: J. Fairgrieve, Geographie und Weltmacht, eine Einleitung in die Geopolitik (Berlin, 1925).

${ }^{37}$ Of the original group, Obst and Maull, formerly co-editors with Haushofer of the Zeitschrift, seem to have dropped out. Most prominent now are Lautenach, Albrecht Haushofer (son), and Baumann. 
ous pamphlets and books, have met with enthusiastic response among the nationalistic reading public in Germany, if not in academic circles. In the reconstruction of education in Nazi Germany, the subject of Geopolitik will apparently occupy that place of importance which its proponents have long been claiming for it. ${ }^{38}$ Whether this is properly to be considered a part of geography, and not rather a part of political science, will be discussed later; at any rate, the work to date has largely been carried on by geographers.

While French geographers have not shown anything like the same interest, there have been many studies of boundaries and border areas by Gallois, Demangeon, de Martonne, and others, as well as two works of major importance. Demangeon wrote on the British Empire as a type study in "colonial geography, an independent branch of knowledge" which should "study the effects arising from the contact between the two types of people who are called upon to associate in a colony, the one civilized . . . the other isolated and self-centered." 39 For such a purpose, it seems unfortunate to have selected the very empire in which self-governing dominions are so important, areas that hardly fit the concept of "colony" from which the author starts.

More important is the theoretical treatise in which Vallaux, whose earlier work has already been mentioned, joined with Brunhes to write La géographie de l'histoire, ${ }^{40}$ which includes a general survey of the field of political geography, based chiefly on Vallaux' earlier Le sol et l'état. Unfortunately, little cognizance is taken of the work done in Germany since Ratzel, and foreign students are disturbed by the marked national prejudice in the second

${ }^{38}$ It is perhaps significant that Kurt Vowinckel, who is not only the publisher of the Zeitschrift für Geopolitik and nearly all the separate publications in Geopolitik, but is in a sense editor (Schriftleiter) of the periodical, is now the appointed head of the publishers' association of Germany. Haushofer, formerly honorary professor at the University of Munich, was in 1933 appointed a regular full (ordinarius) professor.

39 Albert Demangeon, L'Empire britannique: étude de geographie coloniale (Paris, 1923), trans. as The British Empire: A Study in Colonial Geography (New York and London, 1925, German trans., Berlin, 1926).

$40 \mathrm{~J}$. Brunhes and C. Vallaux, La géographie de l'histoire: Géographie de la paix et de la guerre sur terre et sur mer (Paris, 1921). Abstract and review by Douglas Johnson, Geog. Rev., 1922, pp. 278-293. Mention may be made also of J. Brunhes and Deffontaines, "Géographie politique," Pt. 3 of Géographie humaine de la France (Vol. II of G. Hanotaux, Histoire de la nation française, Paris, 1926). 
half of the book dealing with the World War and its settlement.

Recent publications in the English-speaking countries have been equally out of touch with the development of the subject in Germany. In England, the chief workers have been Mackinder, whose earliest work was contemporaneous with Ratzel, and Cornish and Fawcett. ${ }^{41}$ In American geography, Bowman's by-product of the Peace Conference stands alone as a major work. Wright's brief but excellent outline for the historical geography of Europe has already been mentioned. Other publications have been limited to periodical articles by Bowman, Wright, Whittlesey, and others. ${ }^{42}$

\section{DEFINITION OF THE FIELD}

Our brief survey of the history of political geography shows it to be a field in which geographers have not merely laid out claims, but have done a very considerable amount of valuable work. Nevertheless, there is wide divergence of opinion, not only among geographers in general, but also among those working in political geography itself, as to the proper nature of that field and the scope that it should include.

Political Geography Defined as a Study of Relationships. If political geography is to be oriented properly in the general field of geography as a part of human geography, any definition of it must be based on a definition of the field of human geography. ${ }^{43}$ Formerly, most geographers defined human geography in terms of

${ }^{41}$ H. J. Mackinder, "The Physical Basis of Political Geography," Scott. Geog. Mag., VI (1890), p. 73 ff.; Democratic Ideals and Reality (London, 1919); Vaughan Cornish, The Great Capitals; An Historical Geography (London, 1922), very largely political geography; Geography of Imperial Defense (London, 1922); C. B. Fawcett, Frontiers; A Study in Political Geography (Oxford, 1918); A Political Geography of the British Empire (London and New York, 1933).

${ }_{42}$ A number of American geologists have made important studies of problems concerned with the control and production of mineral resources, which are, in part at least, based on economic geography. These include books and articles, chiefly in Foreign Affairs, by Bain, Leith, Spur, and George Otis Smith. A large number are listed in R. H. Whitbeck and O. J. Thomas, The Geographic Factor (New York, 1932), pp. 189-190, 207-209, 231-233.

43 For a discussion of changing concepts of geography, see Alfred Hettner, Die Geographie; ihre Geschichte, ihr Wesen, und ihre Methoden (Breslau, 1927), pp. 73109, 121-131; Febvre, op. cit., 1-67; Carl Sauer, "Recent Developments in Cultural Geography," op. cit.; I. Bowman, Geography in Relation to the Social Sciences, Chap. 1; and "Geography" in Encyclopedia of the Social Sciences, Vol. 6, pp. 621 ff., sections by Sauer, Vallaux, and Sapper. Brunhes' chapter in History and Prospects of the Social Sciences contributes little beyond a detailed discussion of the points of view of Ratzel and Brunhes. 
relationships between earth features, or natural environment, on the one hand, and man with his activities on the other. ${ }^{44}$ Expressed in terms of "geographical control" or "geographic influences," this was, in part, derived from Ratzel's Anthropogeographie, though as Febvre (following Durkheim) shows, it represented only a part of Ratzel's view of the field." That this concept of "environmentalism" has largely dominated the subject for a generation may well be a result, in part, of the fact that geography occupied no independent position in universities, outside of Germany, but was either the handmaiden of history, as in France and Belgium, or of economics, as in England, or was a side-line of geology, as in America. ${ }^{46}$ The students of geography were constantly endeavoring to demonstrate its significance in terms of established fields, and so the subject was defined not so much in its own terms as in terms of its relations to other fields.

Although it is a gross error to assume that Ratzel tried to prove all human activities were geographically determined, ${ }^{47}$ his terminology did lead easily to exaggeration, which Vidal de la Blache, the founder of modern geography in France, met by substituting the concept of "geographic possibilities." Many other geographers have criticized the extremist point of view as vigorously as have critics from the outside, and geographers in general feel justified in being a little weary of the continued attack on the straw-man of "geographic determinism." 48

44 The two great critical studies of this type of geographic work, by Febvre and Thomas, have already been mentioned. Since those were published, there has appeared a significant successor to Miss Semple's great study which is much more moderate in its estimate of the importance of "geographic influences," i.e., Ray H. Whitbeck and Olive J. Thomas, The Geographic Factor; Its Rôle in Life and Civilization (New York, 1932). This book is particularly valuable as a resumé of the work in English and American geography of the last quarter-century.

${ }^{45}$ Op. cit., pp. 51-52.

${ }^{46}$ Douglas Johnson describes these differences in development in "The Geographic Prospect," Annals Assoc. Amer. Geog. (1929), pp. 170-190.

47 "Ratzel does not attempt to explain all political phenomena from environment (aus dem Broden)." Otto Schlüter, rev. in Z. Ges. f. Erdkunde (Berlin, 1898), p. 126.

4 See Bowman's comment on Boas' criticism, Geography in Relation to the Social Sciences, p. 70; and Sauer's comment on Thomas' critique, in "Recent Developments in Cultural Geography," op. cit., p. 170. It is particularly surprising that Thomas' chapter on "The Critics of Geographic Determinism" does not include a single critic from among the geographers themselves. Febvre's study suffers in this regard from having been published ten years after it was written. 
A decade ago, Barrows sought to free geography from the danger of exaggerated claims, which the terms "control" or "influence" had inspired, and which had aroused the attack of social scientists. Reversing the approach, he spoke of man's adjustments to the natural environment, but he maintained the fundamental idea of geography as "a science of relationships." 49

Whichever way the definition is stated, the field for political geography as part of the main field can easily be derived from it: the study of the relations between man's political activities and organizations (including the state, but also parties, etc.) and the natural environment or earth conditions, whether stated directly or conversely. This is clearly the basis, either stated or implied, for the work of Vallaux, Fairgrieve, Newbigin, Fawcett, Brigham, and Semple. As Vallaux puts it, the essential problem of political geography is to determine whether "the life of political societies is determined, in part at least, by the natural frame in which they develop; in what manner the soil, air, and water ... relate themselves to the collective action of men." ${ }^{50}$

With this concept of human geography in mind, Fawcett, in his recent study of the British Empire, states as his object: "to set out and examine those geographical facts which are of direct importance in their influence on the development and organization of the British Empire and its component parts." With such a definition (Fawcett, op. cit., p. v), it is not surprising to find the excellent material of his book presented in a confused mixture of general and political geography.

At the present time, much of the work in Geopolitik in Germany is pursued on a very similar basis. According to the founder, Haushofer, "Geopolitik is the study of the earth relations (Erdgebundenheit) of political occurrences.... The character of the earth's surfaces ... gives to Geopolitik its frame within which the course of political events must [italics mine] take place if they are to have permanent success." ${ }_{51}$

"H. H. Barrows, "Geography as Human Ecology," in Annals Assoc. Amer. Geog., 1922, pp. 1-16; for a favorable response in England, see P. M. Roxby, "The Scope and Aims of Human Geography," Brit. Assoc. Ad. Sc. (Sec. E. Bristol, 1930); also published in Scot. Geog. Mag., 1930, pp. 276-290.

${ }^{\text {so }}$ Le sol et l'etat, pp. 7-8. Similarly in Brunhes and Vallaux, op. cit., pp. 24-25, 267.

${ }^{61}$ Haushofer, Obst, Maull, and Lautensach, Bausteine zur Geopolitik (Berlin, 1928). 
Clearly, such definitions provide the political geographer a wide range for his activities, so wide that it need not surprise one if he reaches far into the area of political science, where his lack of complete training betrays him into fallacious and exaggerated conclusions, to say nothing of gross national partisanship. No wonder then, that in spite of the fruitful work of many of these students, their critics within the field of geography have of ten wanted to ban political geography completely.

An Alternative Definition. Bowman presents a more practical, and at the same time less controversial, definition by suggesting that geography "is also and chiefly a study of the living conditions of mankind as affected by regional combinations of specific soil types ... [and other environmental conditions], together with production habits and possibilities, and landscape effects that give every area its characteristic stamp." ${ }^{2}$ Geography, then, "has political implications because it helps to provide an understanding of the adaptations of group life to the environment of a given area of political control," ... it "helps indicate the scope of national limitations and possibilities." "53 Further, from his critique of Maull's Politische Geographie, we may infer that geography should "offer organized expert knowledge of what we may call the original setup of the world," and "judgments respecting the political set-up of the world today...; rational information of use to policymakers in government." ${ }_{54}$

That the geographer should be able and ready to supply expert knowledge is not to be questioned. But what is the field within which his knowledge may be presumed to be, in fact, "expert"? Few geographers will be in a position to pass judgments on all of the questions which these statements might include. In his own treatment of world problems, Bowman clearly does not intend to keep within any definite limitation of the field.

Geography as the Science of Earth-Areas. In recent decades, many geographers, notably in Germany and Belgium, more recently in this country, have defined their field in terms not of relationships between things, but in terms of the things themselves, namely, the individual areas or regions of the earth, with all the elements, both natural and otherwise, which in their varied combinations, form

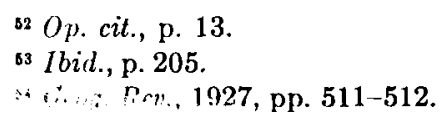


the character of those areas. Hettner shows that this "chorological" conception of geography is far from new. ${ }^{55}$ Based on the concept, as well as the term itself, of Ptolemy and Strabo, it reappeared in the geography of Humboldt and Ritter and was definitely expressed by F. v. Richthofen, who first among modern geographers used the classical term. Ratzel, from whom Semple and others derived their concept of "influences," in fact maintained, both in principle and in practice, in much of his work, the character of geography as the science of areas.

In Germany and Austria, the chorological (or chorographical) view of geography is represented, among others, by Schlüter, Hettner, Passarge, and Maull; in Belgium, by Michotte. In France, where all university work is dominated by the Sorbonne, and geography in particular by the great master, Vidal de la Blache, there is more uniformity of viewpoint, and hence perhaps less discussion of it, than elsewhere. If Brunhes and other students of Vidal are classified with the chorologists, it is not so much on the basis of statements of definitions as of the character of their work. ${ }^{56}$ The great contribution of Vidal is not his change of the word "determinism" to "possibilism," but rather that he focussed the attention of his students, and thereby of all French geography, on the detailed description and analysis of particular regions, rather than the pursuit of principles of relationships. ${ }^{57}$ English geographers have apparently, like the French, been largely out of touch with developments in Germany in recent decades. Stimulated, no doubt, by the brilliant success of the French monographs on regions, and perhaps by the influence of the German-trained Herbertson, ${ }^{58}$ a group of English geographers have recently studied regions in their country. ${ }^{59}$

ss Op. cit., pp. 121-132. See also Sauer, op. cit., pp. 175-182.

${ }^{66}$ Jean Brunhes, La géographie humaine (Paris, 1910, trans. as Human Geography, Chicago, 1920), pp. 4, 13-27, $552 \mathrm{ff}$; and his chapter in History and Prospects of the Social Sciences, pp. 55, 71, 101-102.

s7 Similarly in Germany, Josef Partsch, both by precept and example. The precept is referred to in Brunhes, Human Geography, p. $35 \mathrm{n}$; by example is meant not only his Mitteleuropa (Central Europe in the Mackinder series), but particularly his Schlesien, eine Landeskunde für das deutsche Volk, 2 vols. (Breslau, 1896). After detailed study in that region, I can agree thoroughly with Bowman's comment: "Still one of the best regional studies in the field of modern geography."

68 Sauer classifies Herbertson simply as "an environmentalist" on the basis, apparently, of his Man and His Work (1899); but surely his later concept of "natural regions" is chorographic, and two of his students, using bis notes, have prepared the 
That American geographers have become more interested in the developments in Germany than have either their French or English colleagues is due largely to the vigorous efforts of Carl Sauer, ${ }^{80}$ whose influence has been particularly marked among the younger workers. ${ }^{61}$

First in rank among the geographers who have concerned themselves with the epistemology of their subject is Alfred Hettner. ${ }^{62}$ For him geography is "the science of the earth surfaces, studied according to their local differences, of the continents, lands, regions (Landschaften), and localities." 63 In addition to the study of individual areas, he includes the general comparative study of areas (Länderkunde). In the general system of the sciences, geography is analogous to history; the latter is concerned with the arrangement of phenomena in relation to time, the former in relation to place. One may say that the guiding principle for history is chronology; for geography, it is chorology. Hettner tells us that the philosopher Kant had come to essentially the same conclusion in his analysis of the field of knowledge. ${ }^{64}$

Sauer sums up the position in the statement: "The task of geography is to grasp the content, individuality, and relation of areas." ${ }^{65}$ In further discussion of what is to be studied, he follows chiefly Schlüter and Brunhes in limiting the materials to "observational facts in the landscape," or "the visible, areally extensive and expressive features"

first chorographic text-book in English on Europe: Nora E. MacMunn and G. Coster, Europe; A Regional Geography (Oxford, 1924).

so Great Britain: Essays in Regional Geography, by 26 authors, edit. by Alan G. Ogilvie (Cambridge, 1930).

"0 Carl Sauer, "The Morphology of Landscape," Univ. of Calif. Pub. in Geog., 1925, pp. 19-53; and the articles, previously cited, in Recent Developments in the Social Sciences and the Encycl. of the Social Sciences. As Sauer has noted in several places, Fenneman, in his presidential address in 1918, emphasized "the study of areas as the center of geography": Nevin M. Fenneman, "The Circumference of Geography," Annals Assoc. Amer. Geog., 1919, pp. 3-11.

"1 The current view of many of these is reflected by Preston James in "The Terminology of Regional Description, Annals Assoc. Amer. Geog., July, 1934, pp. 78-86, in particular pp. 81-82.

${ }^{82}$ Sölch, in review in Geografiska Annaler, 1923, p. 323; Sauer in Encycl. Soc. Sciences, Vol. 6, p. 621.

${ }^{83}$ Op. cit., p. 122.

64 Kant's Werke (pub. by Schubert and Rosenkranz), Bd. 2, pp. 425 ff. (after Hettner, op. cit., p. 115).

65 "Recent Developments in Cultural Geography," op. cit., p. 186. 
senses" of Schlüter, or, as some of Sauer's followers in this country express it, "observable features." Hettner directs a sharp criticism against this limitation and points out the later failure of both Schlüter and Brunhes to observe it, as well as the general tendency to drag in by the back door whatever regional facts the qualification "observable" may have seemed to exclude. ${ }^{67}$ Hettner's limitation of the facts to be studied is: "Facts of the earth surfaces which differ from place to place and whose local differences are significant, geographically efficacious, for other phenomena." 68

It must not be supposed that the chorographical concept of geography involves an abandonment of interest in relationships between "earth" and "man." 69 Hettner and Passarge, as well as Vidal de la Blache and Brunhes, all continue to speak in terms of relations between different landscape features, cultural as well as natural. ${ }^{70}$ The difference invalved in the new, or rather, resumed definition is essentially a difference in focus of attention, in the location of the central goal of the science. Geography is again fundamentally a science of places or areas rather than of supposed relations, but in its study of places it is concerned with the causal relations that may be found between the different elements that go to make up the landscape, or the "character," of the place or area. The study of the relationship then is subordinate to, and geographically significant only as a part of, the study of the area, as the quotation from Hettner indicates. On this basis, Vidal accepts "historical events, in so far as they reveal qualities or potentialities of the countries where they occur, which would otherwise remain latent."71

${ }^{66}$ Sauer, in Encyc. Soc. Sciences.

${ }^{67}$ Op. cit., pp. 128-129.

${ }^{68}$ Ibid., pp. 129-130. This limitation protects Hettner from going so far afield as does Banse, who, starting from a definition that includes the spiritual character of the population of an area, is carried into a detailed discussion of what he calls "Seelengeographie des Krieges," in which the races and peoples of the world are divided into war-like and pacifistic, and nice distinctions are made between the fighting quality of troops from Upper and Lower Saxony. Ewald Banse, Raum und Volk im Weltkriege, Gedanken über eine nationale Wehrlehre (Oldenburg, 1932). Banse's more recent work in Wehrlehre has been a matter of some international concern.

69 Preston James recognizes this definitely, loc. cit.

$7^{70}$ S. Passarge, "Wesen, Aufgaben, und Grenzen der Landshaftskunde," Petermann's Mit., Ergän. Heft. 209, 1930, pp. 29-44; Vidal de la Blache, Principes de geographie humaine (Paris, 1922, trans. as Principles of Human Geography, New York, 1926), esp. pp. 3-24. 
Apparently all of these students recognize as a part of geography the comparative study of any particular element of the landscape in its relations to the remainder of the landscape, as found in different regions of the world. Hettner ${ }^{72}$ indeed emphasizes the weakness of individual studies when the student has failed to study this "general geography," as the French and Germans call it, or "systematic geography," as most American geographers prefer to call it.

Political Geography According to the Chorographers. Applying Hettner's definition of the general field, the division, political geography, is the branch of systematic or general geography which concerns itself with those political phenomena of regions differing from place to place and bearing significant relations to other regional phenomena. For those who insist on the limitation to "observational facts," whatever that may mean, the field is rather narrowly restricted to include "the administrative centers, the boundaries (presumably thanks to the boundary-stones-surely a small ticket of admittance), and the defensive lines and positions." 73 However, we might well say with Maull that the state itself constitutes a fact in the cultural landscape as observable as humidity or temperature in the natural landscape, though by many Americans commonly overlooked because of not having observed the differences in another state. ("State" is used throughout in its original sense, as the independent political area, not as one of the United States, for example). Many German geographers have pointed to the effect of the state on a wide range of cultural landscape elements: farms, houses, roads, railroads, trade areas, etc. Conversely, as Maull and many other political geographers have pointed out, the states develop more or less in lands and land types, and constitute in fact "one of the most striking expressions of the effect of landscape (or region-'Landschaft') on the development of the earthly life."74

Schlüter ${ }^{75}$ objects to Maull's concept of the state as a space-

71 Vidal de la Blache, "Les caractères distinctifs de la géographie," Annales de Geog., 1913, p. 299.

72 Op. cit., p. 218.

73 Sauer, "Recent Developments in Cultural Geography," op. cit., p. 208.

7 Maull, op. cit., p. 726. His final claim may be added: "The state is, in the final analysis, a form in the Kulturlandschaft, and its scientific treatment stands therefore at the focus of modern geography." See also Hettner, op. cit., pp. 145-146. 
organism, on the ground that it is a form of human society that is invisible and spiritual. Consequently, political geography, in his view, while an important outlying field of geography, is not a part of geography proper. Brunhes' viewpoint appears on the whole to be similar, though his somewhat illusive discussions are difficult to interpret. The facts of political geography apparently lie "beyond the essential facts," 76 but are included in the purpose of study of human geography;" on the other hand, "political geography is properly only a part of the geography of history," which as a whole belongs to history rather than to geography. ${ }^{78}$

What then is the value in defining narrowly the "proper" field for geography, or its "essential facts," if one recognizes outlying areas of apparently indefinite extent? If geographers may "follow the influence of human geography into the very midst of history" with the sole provision that "they strive never to lose sight of those 'essential facts' which are the 'touchstones' of true geography," 79 there would seem to be no corner of the whole realm of social science in which a somewhat far-sighted geographer might not feel free to work. Thus Brunhes explains why Germany, and Germany alone, wished the War, because of the Prussian tradition and "a geographic necessity" for expansion. ${ }^{80}$ The critical historian or political scientist will hardly accept the author's own judgment that the treatise referred to presents "a study, vigorously and consistently geographical, of the problems presented by the existence, aspirations, and present ambitions of nations." 81

Consequently we return to the conviction that a proper field for political geography should be found within the confines of geography. But a political geography of any major importance cannot accept the limitation of "observational features" narrowly interpreted to mean features directly and physically observable. The fundamental concept of Landschaft, as Passarge or Hettner under-

${ }^{75}$ In his review of Maull's Politische Geographie, Geog. Anz., 1926, pp. 62-66. Maull replies in the same volume, pp. 245-253.

${ }^{76}$ Human Geography, pp. 543-568.

${ }^{77}$ Brunhes, in History and Prospects of the Social Sciences, p. 55.

${ }^{78}$ Ibid., pp. $101 \mathrm{ff}$.

70 Brunhes, Human Geography, p. 552.

${ }^{80}$ Brunhes and Vallaux, op. cit., p. 484. (For the individual responsibility for different chapters, see preface.) Note also Banse's "Seelengeographie des Krieges," footnote 66 .

${ }^{81}$ Brunhes, in History and Prospects of the Social Sciences, p. 73. 
stand it (or "landscape" as James re-defines that word), justifies the following conclusions: political boundaries are a proper object of study by geographers regardless of whether marked by stones or not; and a division into states is one of the major cultural facts of an area (of its Kulturlandschaften), significantly related to many other facts of the cultural and also natural landscape, regardless of whether or not that division is physically observable. ${ }^{82}$

Hettner defines political geography as the study of the space relations of states and their characters, in so far as those are related to other regional phenomena. Passarge similarly says it is the study of the reciprocal relations between space and political organizations. ${ }^{83}$ Vogel's definition is essentially the same, except for the use of "earth" or "earth surfaces" instead of "space." 84 According to Maull, it is the study of "geographic nature (Wesen) and geographic forms of the state or the study of the state in its geographic association (Gebundenheit), in its dependence on the natural and cultural landscape." 85

Disregarding the minor differences between these definitions, we may arrive at a somewhat simpler formulation. If geography according to the "chorologists" is the science of areas, then political geography is the science of political areas, or more specifically, the study of the state as a characteristic of areas in relation to the other characteristics of areas. That such a study will approach, and contribute greatly to, political science, in somewhat the same relation as that of economic geography to economics, does not mean that it need pass the bounds of geography into those of that science. To avoid that, it is necessary to outline more definitely the scope of the field of political geography.

\section{[To be concluded in the next number]}

${ }^{82}$ Hettner, op. cit., pp. 129-132, 145-146, 251. Even Sauer half-recognizes the validity of such a field (more than is here intended), "possibly to be considered as the full regional expression of the political landscape, since it is essentially regional." Op. cit., p. 210.

${ }^{83}$ S. Passarge, "Aufgaben und Methoden der Politische Geographie," in $Z . f$. Politik, 1931, p. 444.

84 Vogel, Politische Geographie, pp. 6-7.

${ }^{8 s}$ Op. cit., p. 44. 